Article

\title{
The Ordinary Legislative Procedure in a Post-Brexit EU: The Case of Social Europe
}

\author{
Paul Copeland \\ School of Politics and International Relations, Queen Mary Univeristy of London, London, E1 4NS, UK; \\ E-Mail: p.copeland@qmul.ac.uk
}

Submitted: 30 September 2020 | Accepted: 21 December 2020 | Published: 27 January 2021

\begin{abstract}
This article assesses the political and power dynamics of the Ordinarily Legislative Procedure (OLP) in social Europe and the likely impact of the UK's departure in the field for future integration. It provides a detailed analysis of the OLP in social Europe during two recent periods of integration in the field-the first Barroso Commission (2004-2009) and the Juncker Commission (2014-2019). It finds the dynamics of the OLP have shifted from intergovernmental deadlock during the Barroso Commission to the characteristics of a new intergovernmental core state power during the Juncker Commission, even though the policy area is not a core state power per se. Despite the use of qualified majority voting policy agreements can only be achieved when there is near unanimity support in the Council, the Commission remains a neutral broker, and the Parliament shifts its position to that of the Council. As a result, continued opposition to integration in social Europe by Northern and Eastern Members means the removal of UK political agency will have only a marginal impact on the slow and piecemeal approach to integration in the field.
\end{abstract}

\section{Keywords}

Community Method; intergovernmentalism; ordinary legislative procedure; post-Brexit; social Europe

Issue

This article is part of the issue "What Brexit Means for Europe: EU Institutions and Actors after the British Referendum" edited by Edoardo Bressanelli (Sant'Anna School of Advanced Studies, Italy) and Nicola Chelotti (Loughborough University London, UK).

(C) 2021 by the author; licensee Cogitatio (Lisbon, Portugal). This article is licensed under a Creative Commons Attribution 4.0 International License (CC BY).

\section{Introduction}

The ordinary legislative procedure (OLP), or the Community Method as it is more commonly referred to, covers approximately $72 \%$ of all subject areas for which the Treaty of the Functioning of the European Union provides for legislative procedures. While knowledge of EU decision-making is less widespread compared to that found within the Member States, as a bicameral law-making procedure, the OLP is a familiar or 'normal' form of decision-making for many citizens of the EU (Roederer-Rynning, 2019). The OLP-referred to as the Co-decision Procedure prior to the 2009 Lisbon Treaty changes-gives the European Commission the right to initiate legislation with the Council of the European Union (herein the Council) and the European
Parliament acting as co-legislators. Following the release of a proposal from the Commission, the Council and the Parliament are required to adopt a legislative proposal at either the first or second reading. The third reading involves the formation of a conciliation committee, whereby representatives from the Council and the Parliament attempt to agree a common text. If a proposal is rejected at any of the two stages, or if no agreement is reached during conciliation, the proposal is not adopted and the procedure ends. At any stage of the OLP the three institutions can enter into trilogues, which are institutionalised informal discussions between the institutions with the view of securing a commonly agreed legislative text (Greenwood \& Roederer-Rynning, 2019). Trilogues have become increasingly common within the OLP to speed up the decision-making process, partly in 
response to the politicisation of European integration. However, as negotiations occur behind closed doors, questions remain as to the democratic credentials of trilogues (Reh, 2014; Roederer-Rynning, 2019).

Theoretically, there is an intense debate regarding the extent to which both the Council and the Parliament are put on an equal footing within the OLP, with debate also extending to the powers of the Commission and its role as an agenda-setter and influencer of decisions (Rhinard, 2010). For example, while qualified majority voting (QMV) can be used in the Council for the OLP, Member States prefer to reach common positions by consensus and thus unanimity voting remains more common (Häge, 2013). Meanwhile, the situation is further complicated by EU's involvement in 'core state powers' such as foreign policy, migration policy and economic policy, which often do not use the OLP. Within core state powers decisions are controlled and steered by intergovernmentalism owing to their national sensitivity, with the Commission and the Parliament often marginalised. This has given rise to the new intergovernmentalism whereby the process of European integration has deepened, but paradoxically, decision-making remains in the hands of the Council (Bickerton, Hodson, $\&$ Puetter, 2015). More recent research suggests that when the OLP is used in core state powers, the Council remains firmly in control of final agreements (Bressanelli \& Chelotti, 2016).

This article draws from the literature on 'new intergovernmentalism' and is focused on two questions: First, what are the political and power dynamics of the OLP within social Europe-referred to as the Social Community Method (SCM)? And second, what is the likely impact of the UK's departure on the future of the SCM? While there are several important studies focusing on certain aspects of the SCM, theorising and evidencing the broader integration dynamics remains scarce (Copeland, 2012; Crespy \& Gajewska, 2010). Meanwhile, the departure of the UK from the SCM-often regarded as one of the EU's main opponents to integration in social Europe-has the potential to shift the integration dynamics. The broader evidence on the dynamics of the field suggests this could be the case. During the first Barroso Commission (2004-2009), when UK political agency was at its highest, agreements via the SCM slowed (Graziano \& Hartlapp, 2019). Meanwhile, during the Juncker Commission (2014-2019) when UK agency was in decline, the SCM had a renaissance (Clauwaert, 2018). In response to these two questions, this article argues that the SCM has shifted from intergovernmental deadlock during the first Barroso Commission (2004-2009) to featuring the characteristics of a core state power of the new intergovernmentalism during the Juncker Commission (2014-2019), even though the SCM is not a core state power per se. This shift is attributed to the EU's attempt to improve its negative image in the wake of the Eurozone crisis rather than a decline in UK political agency. Meanwhile, given the preference for near-unanimity voting in the Council, the removal of UK political agency is unlikely to shift the SCM beyond the slow and piecemeal form of decision-making of the new intergovernmentalism.

The article conducts an in-depth analysis of the SCM during two phases of European integration for social Europe-the first Barroso Commission (2004-2009) and the Juncker Commission (2014-2019). It tracks the usage of the SCM where Treaty provisions specify QMV in the Council. The analysis pays attention to the dynamics between the three main institutions (Council, Parliament and Commission), as well as procedural processes, and the broader process of European integration. The analysis is based on the primary documentation produced by the EU institutions, as well as articles in the specialised press and is complemented by 15 interviews that were conducted between 2006-2020. The interviewees were drawn from the EU institutions and had first-hand experience during the negotiations. The remainder of this article proceeds as follows. The second section explores the relationship between new intergovernmentalism, social Europe, and the potential impact of the departure of UK agency. The third and fourth sections analyse the political and power dynamics of the SCM during the first Barroso Commission and the Juncker Commission. The final section concludes with some reflections on the future of the SCM in the absence of the UK.

\section{The Social Community Method as New Intergovernmentalism}

Theorising decision-making within the EU is complex. Debates over the extent to which the Member States within the Council remain in the driving seat, or have to share power with the Commission and the Parliament, have dominated broader theoretical discussions. The Maastricht Treaty (1992) is said to have formalised two different decision-making systems. The first is the Single European Market which is governed by the OLP. The OLP gives the Commission the right to initiate legislation and as both the Council and the Parliament are required to reach an agreement for legislation to be passed, it places the two institutions on an equal footing. Within the Council agreement is secured by a QMVwhen $55 \%$ of the votes allocated to the Member States are in favour representing at least $65 \%$ of the population. By contrast, within the Parliament an agreement is secured by a simple majority vote. The usage of the OLP suggests a supranational decision-making arena, i.e., the pooling of sovereignty in which Member States lose their veto and decision-making is shared with other EU actors. The second decision-making system is the EU's expansion into new sensitive policy areas where integration entails high sovereignty costs for the Member States, such as foreign policy, migration and financial cooperation, and is largely directed by intergovernmental institutions. As Schimmelfenning notes $(2015$, p. 6), the policies that best suit the latter integration dynamics are 'core 
state powers,' that is, integration entails high sovereignty and identity costs for the Member States (Genschel \& Jachtenfuchs, 2013).

Theoretically, this dual system of decision-making has given rise to the 'new intergovernmentalism.' New intergovernmentalism has its origins in liberal intergovernmentalism, which, at its most fundamental level, assumes that during Treaty changes and conditions of unanimity voting, the Member States remain in the driving seat and bargain hard to reach an agreement (Moravcsik, 1998). The logic of liberal intergovernmentalism is extended to the new intergovernmentalism whereby deeper integration into core state powers has not resulted in more supranationalism. However, as noted by Bressanelli and Chelotti (2016, p. 513), the analytical distinction between the intergovernmental method and the OLP conceals that complex interactions between the two may exist in different policy fields. Research conducted by the authors demonstrates how new intergovernmentalism extends to the OLP. In the wake of the Eurozone crisis, the EU introduced various reforms to EU economic governance, including two legislative packages - the Six-pack and the Two-packwhich were negotiated via the OLP. The negotiations, however, gave a strong role to the European Council as an agenda-setter, and in the legislative negotiations, the Parliament played a more limited role and correlated with the positions of the Council. While Treaty provisions enable the use of QMV in the Council, in economic governance there is a preference for agreement via unanimity.

The EU's competence in employment and social policy is predominantly a spillover of integration within the Single European Market (Leibfried, 2010). The EU has been responsible for the harmonisation of Member State policies in several key areas to ensure the Single European Market does not lead to a lowering of labour standards or the distortion of competition. Articles $46-48$ enable the OLP to be used for the coordination of social security systems to promote the free movement of workers. Article 153 enables the OLP (with QMV) to be used to agree minimum standards in health and safety, working conditions, the information and consultation of workers, and equality between men and women with regard to labour market opportunities and treatment at work. Article 153 also enables EU directives to be agreed in other areassocial security and social protection of workers, the protection of workers where their employment contract is terminated, employee influence within enterprises (co-determination), and the employment conditions of third-country nationals-but decisions require the Council to act unanimously with the Parliament being consulted. Nevertheless, given the diversity of EU welfare states, reaching agreements on minimum standards is difficult. The overall result has been a slowing of agreements over the last two decades and explains the EU's turn to legally non-binding governance tools, such as the Open Method of Coordination (ter Haar \& Copeland,
2010; Zeitlin, Pochet, \& Magnussen, 2005). This leads to the first research question: What are the political and power dynamics of the SCM?

A second consideration is the impact of the UK'S departure on the SCM. The UK has long been a staunch opponent of EU directives in the field. In 1989 it declined to sign the Community Charter of Fundamental Social Rights of Workers, which aimed to create a level playing field in social policy (Copeland, 2014). At the signing of the Maastricht Treaty changes, the UK also declined to sign the Community Charter. The Charter contains 30 principles to guide EU social policy and the 11 Member States were allowed to integrate in social policy without the UK, but political division hindered substantive progress. Meanwhile, UK opposition to the 1993 Working Time Directive (WTD) resulted in the inclusion of the famous opt-out. The Directive limits the number of hours an individual can work to 48 per week (calculated as an average over a reference period of four months) and also specifies other provisions including minimum rest periods and the entitlement to four weeks paid annual leave per year. The opt-out enables Member States not to apply the maximum 48-hour limit and the UK was the only Member State to make full use of it. Further opposition from the UK promoted it to challenge the legal basis of the WTD in the European Court of Justice (ECJ). The UK claimed that working time was not a health and safety matter, but this view was not shared by the ECJ who ruled against the UK in its 1996 judgement (Blair \& Leopoid, 2001). Meanwhile, 2010's Conversative Party Manifesto pledged to return certain powers from the EU including those concerning employment legislation (Conservative Party, 2010). The departure of the UK from SCM suggests a potential easing of the difficulties posed by reaching agreements in the Council, resulting in the second research question: What is the likely impact of the UK's departure on the future SCM?

\section{The Social Community Method during the First Barroso Commission (2004-2009)}

During the first Barroso Commission, the SCM procedure featured entrenched political division both within the Council and the Parliament, as well as between the two institutions. Within the Council, Member States were divided between those who favoured a more expansive and market-correcting role for the social Europe and those who preferred a minimal market-making role (Höpner \& Schäfer, 2010). Within the Parliament MEPs, especially those from the main centre-left (Socialists and Democrats-S\&D) and centreright (European People's Party-EPP) groupings predominantly voted along national lines during policy negotiations. Meanwhile, both Barroso Commissions took a consistent political position and sided with liberalleaning Member States, such as the UK and the 2004 Central and Eastern European States, during policy negotiations (Copeland, 2012). The overall result was 
one of intergovernmental deadlock in the decisionmaking process with the Council remaining in the driving seat. The negotiations surrounding the revision of the Working Time Directive (WTD) and the Temporary Agency Workers Directive (TAWD) serve as example.

The original WTD contained two review clauses which required the opt-out and the calculation of the reference period to be reviewed prior to 2003. Furthermore, prior to the review, two rulings by the ECJ clarified a legal uncertainty within the Directive regarding on-call time (Landeshauptstadt Kiel v. Norbert Jaeger, 2003; Sindicato de Médicos de Asistencia Pública v. Conselleria de Sanidad y Consumo de la Generalidad Valenciana, 2000). The rulings clarified that all on-call time spent within the workplace, regardless of whether it was spent active or inactive, was to be regarded as working time. Most EU healthcare systems across the EU-including ardent supporters of the WTD, France and Spain-had interpreted the Directive with only active oncall time regarded as working time. Both the Commission and the Council were anxious to get the matter resolved, not least because they disagreed with the ECJ's rulings (interviews A, C, D). The Commission tabled a revision of the Directive in September 2004, which maintained the use of the opt-out, extended the reference period from four to 12 months, and proposed active on-call time should be regarded as working time (European Commission, 2004).

Within the Council, most delegations were in favour of the Commission's proposal for on-call time, but political division centred on the opt-out and the reference period (interviews A, D, E). Belgium, Greece, France, Portugal, Spain and Sweden formed a broad coalition opposed to the Commission's proposal on the opt-out. The UK, along with some of the 2004 new Member States, such as Poland, Slovakia and Malta, were in favour of the Commission's proposal, while the remaining Member States abstained from declaring their position during the early stages of the negotiations (Council of the European Union, 2004). The political agency of France and Spain on the one hand, and the UK (and eventually Germany) on the other, was to prove crucial in the entrenching of divisions, the resultant political stalemate, and the inability of the EU to agree on a revised directive (interviews D, E). Crucially, for France and Spain, Alejandro Cercas, a Spanish MEP from the S\&D was appointed as the rapporteur in the Parliament and was sympathetic to their position (interview F). The UK, concerned France and Spain would gain the upper hand during the negotiations, went on the offensive and secured the backing of Germany. The agreement reached between Berlin and London was that Germany would support the UK on the WTD in return for British support on the Takeover Directive (Financial Times, 2004). This agreement inadvertently brought other Northern Member States into the group of countries supporting the Commission's proposal and the overall result was one of political deadlock (interview D).
With little progress in the Council, attention shifted to the European Parliament, where the rapporteur was able to secure a $58 \%$ majority $(381 / 653)$ in the plenary vote which rejected the Commission's proposal-it voted to maintain the opt-out and for a calculation of on-call working time, regardless of whether it was spent active or inactive, to be fully included in the calculation of working time (Keter, 2009). Voting within the Parliament was more likely to be driven by intergovernmental decisions, rather than MEPs acting as in accordance with their political groupings. The strongest support in the Parliament for removing the opt-out and thereby supporting the rapporteur came from France with $97 \%$ of its MEPs voting in favour, followed by Greece (90\%), and Portugal (89\%). MEPs who voted against the proposals and wished to maintain the opt-out predominantly came from Poland (75\%), Ireland (73\%), the Czech Republic (67\%), Latvia (60\%), Slovenia (57\%) and the UK (56\%; calculated from roll call vote-see European Parliament, 2020).

Following Parliament's rejection of the Commission's proposal, the Commission intervened and claimed the Parliamentary amendments "did not constitute an improvement to the directive" and would "make it more difficult to obtain an agreement or a sufficient majority in the Council" (European Commission, 2005, p. 3). The Commission more or less reverted back to its original proposal and appeared to be siding with the UK and its liberal allies. This further polarised political division, as the Commission lost its reputation for being a broker during negotiations (interview $\mathrm{B}$ ). Within the Council, the negotiations passed through various Council Presidencies, including that of the UK in the latter half of 2005, followed by Austria and Finland. Deadlock in the European Council was finally resolved during the 2008 Slovenian Presidency. In 2007 the Portuguese Presidency linked the revision of the WTD to the proposed TAWD. The latter had been stuck in co-decision since 2004 and it was hoped a simultaneous negotiation of the two directives would allow Member States "to find a balance between the two directives that would be acceptable from a political point of view" (Council of the European Union, 2007, p. 8). The negotiations would produce something for both coalitions and enabled no one side to lose face, particularly France and the UK (interviews D, F). The UK signalled it was willing to compromise on the TAWD while France, with the recently elected President, Nicolas Sarkozy, was also willing to compromise on the WTD. In June 2008 the European Council agreed on a compromise-the revised WTD would maintain the opt-out and contain a definition of on-call time that split active and inactive work for the purposes of calculating the maximum working week. On TAWD, it was agreed employees were to be given equal treatment as of day one with respect to pay, maternity leave and annual leave (European Commission, 2008, September 6).

The compromise within the Council was met with bitter disappointment within the Parliament (interview $\mathrm{H}$ ). 
Meanwhile, MEPs were also acutely aware that the 2009 elections were looming and, under the Barroso Commission, there were few policy outputs for social Europe (interviews $\mathrm{G}, \mathrm{H}$ ). Under the steering of the rapporteur, Alejandro Cercas, the Parliament took the decision to split the two directives (Europolitics, 2008). For the TAWD, the Committee of Employment and Social Affairs (EMPL) adopted, by near unanimity, the Council's amendments, which had been agreed at second reading, but initially opposed by the Parliament. With respect to the WTD, the Committee reverted to the Parliament's 2004 position and secured a 54\% majority (421/785) in favour of its proposal. As in the first round of plenary voting, MEP voting patterns crossed party lines, and with the exception of France, demonstrated a strong correlation with their government positions in the Council, albeit there were some minor shifts. The strongest support came from Spain with $100 \%$ of MEPS in favour of maintaining the opt-out, followed by Portugal (96\%), Hungary (91\%), Italy (74\%) and France (72\%). $100 \%$ of MEPs from Latvia and Malta voted against the removal of the opt-out, followed by the UK (73\%), Slovenia (71\%), Slovakia (70\%) and Czech Republic (68\%; calculated from roll call vote-see European Parliament, 2020). Following two failed attempts of negotiation between the Council and the Parliament, the WTD moved to conciliation, but the third and final round of negotiations between the Parliament and the Council could not reach an agreement.

During the first Barroso Commission the SCM featured intergovernmental deadlock with entrenched positions in the Council and the Parliament, as well as division between the two institutions. Towards the end of the Commission, deadlock between the two institutions could only be overcome by opportunism in the Parliament. While the political agency of the UK, supported by the Commission, undoubtedly contributed to the dynamics, the preference for near unanimity decision-making in the Council, rather than QMV, limits the agency of one Member State. Opposition to certain agreements in the SCM is a position taken not just by the UK, but is one also shared by Northern and Eastern Member States. Meanwhile, further contextualising the limits of UK agency in the SCM was its willingness to support a compromise on the TAWD to secure agreement on the WTD. In this regard, while the UK has been an important obstacle to certain developments within the SCM, it has not been alone and has also been willing to compromise.

\section{The Social Community Method during the Juncker Commission (2014-2019)}

Developments within the SCM from 2014 onwards need to be understood in the context of the shifting sands of the previous decade. The siding of the Barroso Commission (and the second Barroso Commission) with the neo-liberal-leaning faction of Member States and the deterioration of relations between the Council and the Parliament resulted in a slowing of Directives in social Europe. Meanwhile, the 2009 Parliamentary elections returned the largest share of representation from populist far-left and far-right parties, only for their share of the vote to be superseded by the 2014 elections. Both the EPP and the S\&D were concerned that the rise of populism, and its impact on their share of the vote, were being bolstered by the limited progress in social Europe and the fallout from the Eurozone crisis (interviews $M, N$ ). On the latter, the pursual of EU-driven austerityassociated with cuts to government spending and a liberalisation of employment protection-undermines employment and welfare regimes (Blyth, 2013).

Upon appointment of the Juncker Commission, there was thus a broad, albeit loosely defined, commitment to a renewed momentum in social Europe, including in the European Council. To obtain support in the Parliament from both the EPP and the S\&D for his nomination, Juncker made specific commitments to be more proactive on social Europe (Stupp, 2017). The politics of Juncker vis-à-vis Barroso is also important from the perspective of the social Europe. While both are drawn from the EPP, Barroso is from the liberal-conservative tradition that supports a minimal and market-making welfare state, while Juncker is drawn from the Christian Democrats which is more centre-left on employment and social policy matters. This helped to smooth relations between both the EPP and the S\&D in the Parliament. Juncker also benefited from being a Brussels insider, having being President of the Eurogroup (2005-2013), as well as being one of the key drivers behind the launching of the European Employment Strategy (1997) during his time as the Luxembourg Minister for Work and Employment. Meanwhile, throughout the Juncker Commission a preoccupation with the UK's referendum on EU membership reduced the political agency of one of the main players opposed to EU legislation in social Europe. However, the renewed momentum within the SCM was achieved by a shift within the political and power dynamics of the SCM from intergovernmental deadlock to that of the new intergovernmentalism, thereby demonstrating the Council remains firmly in control of the process of integration and will remain so post-Brexit.

The Commission's legislative agenda launched in April 2017, although some policy issues had been in the pipeline during the previous year, such as the Revision of the Posting of Workers (Clauwaert, 2018, pp. 87-89). The broad legislative strategy included four initiatives: the revision of the Written Statement Directive (91/533/EC); a proposed new directive on Work-Life Balance for Parents and Carers; an interpretative guidance on the Working Time Directive (2003/88/EC); and a consultation on improving access to social protection for all workers, including the selfemployed (European Commission, 2017a). These were followed by two further initiatives in March 2018, 
including a Regulation establishing a European Labour Authority and a Council Recommendation on access to social protection for all workers, including the selfemployed (European Commission, 2018, March 13). By the end of its term in office, the Juncker Commission had secured agreements via the SCM for two main pieces of legislation-the Transparent and Predictable Working Conditions Directive (TPWCD) and the Work-Life Balance Directive (WLBD). However, these two agreements could only be secured on matters for which there was near unanimity agreement within the Council; the Commission remained a neutral broker, and the Parliament was required to shift its position towards that of the Council. The Council therefore remains in the driving seat of European integration in the context of new intergovernmentalism.

In a departure to the Barroso Commission, the Juncker Commission attempted to gain broader legitimacy for its legislative agenda. This came in the form of the European Pillar Social Rights (EPSR)-launched at the 17 November 2017 Social Summit for Fair Jobs and Growth in Gothenburg. The EPSR sets out 20 common principles/rights, categorised into three chapters with a total of 51 sub-sections covering: equal opportunities and access to the labour market; fair working conditions; and social protection and inclusion (European Commission, 2017b). The launching of the ESPR also included documents setting out how it would be actioned, including the Commission's legislative initiatives launched in 2017 and later in 2018. In essence, the ESPR is a repacking of existing social rights within the EU Treaties with the addition of new groups or policy issues-such as a right of the self-employed to social protection, and a set of rights in regard to services, e.g., long-term care and housing. The latter additions are legally non-binding, as the EU has limited or no legal competence in the areas included within its expansive approach. Within the European Council, a group of Northern and Eastern Member States were opposed to an extension of social rights-this included the 'Frugal Four' (Austria, Denmark, the Netherlands and Sweden), as well as Germany, Hungary, Poland and the UK (interviews I, K, O). Despite preparing for the UK's withdrawal of the EU, the then UK Prime Minster, Theresa May, also signed up to the ERSR owing it maintaining the current status quo (interviews I, J). In this regard, the EPSR should be viewed as a rhetorical device aimed at establishing a policy framework for future action and gaining a very public commitment from the key players within the SCM for policy agreements. With EU leaders and the Parliament all signed up to the ESPR in a very public display of commitment, the stage was set for concrete policy outcomes.

Agreements moved quickly on the TPWCD and the WLBD. On the former, the original Written Statement Directive was agreed in 1992 and gives employees the right to be notified in writing the essential aspects of their employment relationship within two months of employment commencing. The 'written statement' includes information such as pay, job description, the duration of contract, paid leave and notice period. Meanwhile, the latter is a revision of the Maternity Leave Directive (1992), which had been stuck in the SCM since the Barroso Commission launched a revised directive in 2008. In 2015 the Juncker Commission withdrew the proposed 2008 revision and announced it would replace the original Directive, as well as the 2010 Parental Leave Directive concluded by the social partners. In essence, the Directives were updates to two existing pieces of legislation where there was broad agreement they were out of step with current labour market conditions (interviews I, K).

For the TPWCD, the Commission's proposal included new minimum rights, such as: the right to greater predictability of work for those working mostly with a variable schedule; for those working unpredictable hours, the right to request permanent employment (after six months); and the right to mandatory training without a deduction from salary. Meanwhile, workers were to be informed of their employment rights from the first day of employment and workers were defined in accordance with ECJ case law. The latter brought forms of employment often excluded from EU legislation, such as domestic workers, marginal part-time workers, and extending it to new forms of employment, such as on-demand workers, voucher-based workers and platform workers (European Commission, 2017c). The Council agreed a general approach on the proposal on 21 June 2018 and included a number of amendments, such as: exempting workers in public service (e.g., armed forces, police, etc.); increasing the number of hours needed for the directive to apply from eight per month to five hours per week; providing essential information for the written statement during the first week of employment and the remainder within the first month; and removing the ECJ definition of worker (Council of the European Union, 2018). Within Parliament, the file was referred to the EMPL, where Enrique Calvet Chambon (ALDE, Spain) was appointed as rapporteur. EMPL adopted its report on 18 October 2018 and, contra to the Council: supported the inclusion of the ECJs definition of a worker; called for adaption, rather than exemption of the Directive for workers in public service; preferred the 'written statement' was to be provided within one week of employment commencing; and introduced several safeguards to prevent abuse arising from on-demand contracts. This adoption was not without some political infighting, as conservatives within the EPP and the European Conservatives and Reform Group, arguing the Parliament's amendments would create less flexible working conditions, unsuccessfully attempted to block the report (Socialists and Democrats, 2018).

The Commission's proposed WLBD included several new or higher minimum standards for parental, paternity and carer's leave, such as: the new right for fathers/second parents to 10 days leave around the birth 
of a child; four months parental leave for children up to the age of 12 years compared to the current non-binding age of eight-the latter being an individual right for parents without the ability to transfer leave between parents; 5 days carer's leave; and the right to request flexible working to all parents up to the age of 12 . All familyrelated leave arrangements were to be compensated to the level of at least sick pay. The proposed measures were intended to increase possibilities for men to take up parental and caring responsibilities, but the Council of Ministers was unhappy with the generosity of the proposals (European Commission, 2017d). At the June 2018 Council meeting there was no particular patterning to Member State positions and there was a broad consensus to reach an agreement (interview K). Delegations agreed on the right to request flexible working, but this was reduced to children under the age of eight. It was agreed that renumeration for paternity leave and 1.5 months of parental leave would be determined in accordance with national practices, rather than EU harmonisation. Finally, two months of parental leave could be transferred between parents, creating a situation whereby eight months of parental leave could be shared between parents. Whilst Poland, Hungary and the Baltic States would have preferred the existing status quo of one month of transferring parental leave, the various changes introduced proved sufficient for a compromise (Bulletin Quotidien Europe, 2018).

The European Parliament, particularly within the S\&D, claimed the Council had severely weakened the Commission's proposal. Meanwhile, the EPP rapporteur, David Casa, was also in favour of more extensive provisions than those given by the Council. His report, adopted in July 2018 by a majority in EMPL, focused on renumeration for paternity, parental and carer's leave, with workers to receive payment equivalent to $75 \%$ of their gross wage during their leave. On the issue of parental leave, all working parents were entitled to request flexible working arrangements up until the age of 10; and on the transferring of parental leave, the Parliament maintained the Commission's initial proposal of it being a non-transferable right (European Parliament, 2018). As with the proposed TPWCD, the Parliament and the Council were some distance from each other. With the 2019 Parliamentary elections pending, it was the Parliament that compromised to reach agreement (interview $\mathrm{M}$ ). To speed up the decision-making process both rapporteurs secured agreement in Parliament (via plenary votes) to enter into trilogues-for the WLBD this was secured in September 2018 and for the TPWCD it was secured in November 2018. Over the last decade the usage of trilogues has increased, as the bypassing of the various formal stages of the OLP speeds up agreement between the Council and the Parliament, but this is at the expense of openness and transparency, as negotiations occur behind closed doors (Curtin \& Leino, 2017). The political dynamics of both trilogues is something of a black box. However, in contrast to the Barroso
Commissions, the Juncker Commission refused to position itself on either side of the debate-it stressed the importance of both the Council and the Parliament needing to reach agreement and this potentially helped to smooth relations between the two sides (interview K).

Comparing the final agreements to the original positions of the Council and the Parliament reveals it was the Parliament who compromised the most and shifted to the Council's position. On WLBD the final agreement was reached in January 2019. The agreement gave 10 days paternity leave, paid at the rate of sick pay. On parental leave, renumeration was to be determined at national level, with two months non-transferable between parents. Carers were entitled to five days leave, but this was to be unpaid, while flexible working for employees could be requested for children up to the age of eight. In essence, the final agreement was near identical to the June 2018 common position agreed in Council, albeit with some minor modifications. The final agreement was adopted by Parliament during the April 2019 plenary with $77 \%$ of MEPs in favour (470 for, 126 against, 18 abstentions; European Parliament, 2019a). For the TPWCD, the final agreed version of the directive removed any definitions relating to 'worker,' 'employer' and 'employment relationship.' The written statement can be provided in two stages, with essential information provided within seven days of employment commencing and supplementary information given within one month. Finally, the directive is to apply to individuals working a minimum of 12 hours per month and excludes certain categories of public sector employees. In Parliament, again the April plenary vote was similar to that of the WLBD-74\% of MEPs in favour (466 for, 125 against, 37 abstentions; European Parliament, 2019b).

Under the Juncker Commission, the intergovernmental deadlock of the SCM evolved to the new intergovernmentalism. That is, agreements were secured when there was near unanimity support in the Council and the Parliament shifted its position to that of the Council. In this regard, decision-making in the SCM corresponds to the features of a core state power of the new intergovernmentalism, even though it is not a core state power per se. The changing dynamics of the decisionmaking process stem from a shift within the Commission and the Parliament in the wake of the negative reputational consequences of the Eurozone crisis for the EU. In particular, to secure agreement via the SCM the Parliament dropped its long-held position of pushing for more generous provisions within the proposed directives. Meanwhile, during the Juncker Commission, UK political agency was also in decline, but the revival of the SCM stemmed from the broader political context and the focusing of minds in the EU institutions. Given the preference for near unanimity agreement in the Council for the SCM, future agreements without the UK will continue within the framework of the new intergovernmental decision-making and as a result, difficult to achieve. Northern and Eastern Members remain opposed to 
integration in the field, as demonstrated during the Juncker Commission. While the Juncker Commission was able to move forward on directives where there was a broad consensus in the Council, other controversial areas avoided being introduced into the SCM. In the field of extending social protection to all workers, the Commission launched a public consultation, but opposition from Northern and Eastern Members resulted in the Commission deciding against the proposing of a directive. The Commission opted for a legally non-binding Recommendation whereby the Commission and the Council monitor-via the European Semesterthe access to social protection (interviews $\mathrm{K}, \mathrm{O}$ ).

\section{Conclusion}

This article has focussed on two research questions: What are the political and power dynamics of the SCM? And what is the likely impact of the UK's departure on the future of the SCM? Analysing the political and power dynamics of the SCM reveals the shift from intergovernmental deadlock during the first Barroso Commission to the features of a new intergovernmental core state power during the Juncker Commission, even though the field is not a core state power per se. The deadlock of the Barroso Commission can be accounted for by the inability of the Parliament to agree with the Council. The very political position taken by the Barroso Commissionits siding with more liberal forces in the Councilfurther polarised division between the Parliament on the one hand and the Council on the other. The renewed moment in the field during the Juncker Commission stemmed from the shifting positions of the Parliament to the position of the Council. Concerned by the rise of populism in the 2014 general elections, the Parliament was less willing to exercise its authority to secure agreement. This was further helped by the Commission behaving as a neutral broker and its launching of the EPSR, which acted as a rhetorical device to galvanise agreement.

Given the political and power dynamics of the SCM, the removal of UK agency is unlikely to shift the field beyond its current new intergovernmental constraints. When UK political agency was at its highest during the first Barroso Commission, the political stalemate of that period can be accounted for by several factors, of which the UK agency is one. During the Juncker Commission, the renewed momentum in the SCM corresponded with a decline in UK agency, but agreements were secured by the Parliament shifting its position during the negotiations to that of the Council. It is also telling where legislative agreements were secured, and not secured, during the Juncker Commission. Both the TPWCD and WLBD represent an extension of rights to EU workers, but in the grand scheme of EU employment regimes they remain a somewhat marginal development-the UK, for example, has more extensive employment provision in many of the areas covered by the two Directives. More substantive reform, such as extending social protection to new forms of employment, were quickly blocked by the Council. Northern and Eastern Member States are particularly opposed to further integration in the field and their opposition will remain post-Brexit. If social Europe is to deepen over the coming decades, it will require a fundamental rethink within the Council and need to move beyond the framework of new intergovernmentalism.

\section{Acknowledgments}

I am grateful for the comments made by two anonymous reviewers and the editors.

\section{Conflict of Interests}

The author declares no conflict of interests.

\section{References}

Bickerton, C. J., Hodson, D., \& Puetter, U. (2015). The new intergovernmentalism: European integration in the post-Maastricht era. Journal of Common Market Studies, 53(4), 703-722.

Blair, A., \& Leopoid, J. (2001). An awkward partner? Britain's implementation of the working time directive. Time and Society, 10(1), 63-76.

Blyth, M. (2013). Austerity: The history of a dangerous idea. Oxford: Oxford University Press.

Bressanelli, E., \& Chelotti, N. (2016). The shadow of the European Council: Understanding legislation on economic governance. Journal of European Integration, 38(5), 511-524.

Bulletin Quotidien Europe. (2018). Council of the EU preparing its position on three highly political legislative texts. Agence Europe. Retrieved from https:// agenceurope.eu/fr/accueil.html

Clauwaert, S. (2018). A new legislative agenda for the EU: Putting meat on the bones after all? In B. Vanhercke, D. Ghailani, \& S. Sabato (Eds.), Social policy in the European Union: State of play 2018 (pp. 73-96). Brussels: ETUI.

Conservative Party. (2010). Invitation to join the Government of Britain. London: Conservative Party.

Copeland, P. (2012). EU enlargement, the clash of capitalism and the European social model. Comparative European Politics, 10(4), 476-504.

Copeland, P. (2014). EU enlargement, the clash of capitalism and the European social dimension. Manchester: Manchester University Press.

Council of the European Union. (2004). Meeting document, Permanent Representation Committee, 2075th meeting on 1 and 3 December 2004 (DS 817/1/04 [soc]). Unpublished document.

Council of the European Union. (2007, December 6). 2837th Council meeting: Employment, social policy, health and consumer affairs [Press release]. Retrieved from https://www.consilium.europa.eu/ ueDocs/cms_Data/docs/pressData/en/Isa/97445.pdf 
Council of the European Union. (2018). Proposal for a directive of the European Parliament and of the Council on transparent and predictable working conditions in the European Union (2017/0355). Brussels: European Commission.

Crespy, A., \& Gajewska, K. (2010). New parliament, new cleavages after the Eastern enlargement? The conflict over the services directive as an opposition between the liberals and regulators. Journal of Common Market Studies, 48(5), 1185-1208.

Curtin, D., \& Leino, P. (2017). In search of transparency for EU law making: Trilogues on the cusp of dawn. Common Market Law Review, 54(6), 1673-1712.

European Commission. (2004). Proposal for a directive of the European Parliament and of the council amending directive 2003/88/EC concerning certain aspects of the organisation of working time (COM (2004) 607 Final). Brussels: European Commission.

European Commission. (2005). Amended proposal for a directive of the European Parliament and of the Council amending directive 2003/88/EC concerning certain aspects of the organisation of working time (COM (2005) 0246 Final). Brussels: European Commission.

European Commission. (2008, September 6). Commission strongly welcomes today's political agreement on working time and working conditions for temporary agency workers [Press release]. Retrieved from https://ec.europa.eu/commission/presscorner/ detail/en/IP_08_912

European Commission. (2017a). Communication from the Commission to the European Parliament, the Council, the European Economic and Social Committee and the Committee of the Regions: Establishing a European pillar of social rights (SWD(2017) 201 final). Brussels: European Commission.

European Commission. (2017b). Establishing a European pillar of social rights (COM (2017) 250 Final). Brussels: European Commission.

European Commission. (2017c). Proposal for a directive of the European Parliament and of the Council on transparent and predictable working conditions in the EU (COM (2017) 0797 Final). Brussels: European Commission.

European Commission. (2017d). Proposal for a directive of the European Parliament and of the Council on worklife balance for carers and repealing Council directive 2010/18/EU (COM (2017) 0253 Final). Brussels: European Commission.

European Commission. (2018, March 13) Commission adopts proposals for a European Labour Authority and for access to social protection [Press release]. Retrieved from https://ec.europa.eu/commission/ presscorner/detail/en/IP_18_1624

European Parliament. (2018). Report on the proposal for a directive of the European Parliament and of the Council on work-life balance for parents and carers and repealing Council directive (2010/18/EU, A8-
0270/2018). Brussels: European Parliament.

European Parliament. (2019a). Position of the European Parliament adopted at first reading on 4 April 2019 with the view of the adoption of directive (EU) 2019/...of the European Parliament and the Council on work-life balance for parents and carers repealing Council directive 2010/18/EU (EP-PE_TC1-COD (2017)0085). Brussels: European Parliament.

European Parliament. (2019b). European Parliament legislative resolution of 16 April 2019 on the proposal for a directive of the European Parliament and of the Council on transparent and predictable working conditions in the European Union (COM(2017)0797-C80006/2018-2017/0355 (COD)). Brussels: European Parliament.

European Parliament. (2020). Organisation of working time 2004/0209 (COD). European Parliament Legislative Observatory. Retrieved from https://oeil. secure.europarl.europa.eu/oeil/popups/ ficheprocedure.do?lang=en $\&$ reference $=2004$ $\% 2 f 0209$ (COD)

Europolitics. (2008, December 8). Working time directive: EP committee says no to Council. Europolitics. Retrieved from https://www.europolitics.com

Financial Times. (2004, March 29). UK gains German support over working hours. Financial Times. Retrieved from https://www.ft.com

Genschel, P., \& Jachtenfuchs, M. (2013). Beyond the regulatory polity? The European integration of core state powers. Oxford: Oxford University Press.

Graziano, P., \& Hartlapp, M. (2019). The end of social Europe? Understanding EU social policy change. Journal of European Public Policy, 26(10), 1484-1501.

Greenwood, J., \& Roederer-Rynning, C. (2019). Taming trilogues: The EU's law-making process in a comparative perspective. In O. Costa (Ed.), The European Parliament in times of EU crisis: Dynamics and transformation (pp. 121-141). Basingstoke: Palgrave Macmillan.

Häge, F. (2013). Coalition building and consensus in the Council of the European Union. British Journal of Political Science, 43(3), 481-504.

Höpner, M., \& Schäfer, A. (2010). A new phase of European integration: Organised capitalisms in postRichardian Europe. West European Politics, 33(2), 344-368.

Keter, V. (2009). Working time directive: Opt-out from 48 hour limit on working week (SN/BT/2073). London: House of Commons Library.

Landeshauptstadt Kiel v. Norbert Jaeger, 2003:209 (2003)

Leibfried, S. (2010). Social policy: Left to the markets and the judges. In H. Wallace, W. Wallace, \& M. Pollack (Eds.), Policy-making in the European Union (pp. 253-282). Oxford: Oxford University Press.

Moravcsik, A. (1998). The choice for Europe: Social purpose and state power from Messina to Maastricht. Ithaca, NY: Cornell University Press. 
Reh, C. (2014). Is informal politics undemocratic? Trilogues, early agreements and the selection model of representation. Journal of European Public Policy, 21(6), 822-841.

Rhinard, M. (2010). Framing Europe: The policy shaping strategies of the European Commission. Dordrecht: Republic of Letters Publishing.

Roederer-Rynning, C. (2019). Passage to bicameralism: Lisbon's ordinary legislative procedure at ten. Comparative European Politics, 17(6), 957-973.

Schimmelfenning, F. (2015). What's the news in 'new intergovernmentalism?' A critique of Bickerton, Hodson and Puetter. Journal of Common Market Studies, 53(4), 723-730.

Sindicato de Médicos de Asistencia Pública v. Conselleria de Sanidad y Consumo de la Generalidad Valenciana, 2000:528 (2000)

Socialists and Democrats. (2018, November 15). S\&Ds defend EU workers' right in the face of challenge from conservatives in the European Parliament [Press release]. Retrieved from http://pr.euractiv.com/ $\mathrm{pr} / \mathrm{sds}$-defend-eu-workers-right-face-challengeconservatives-european-parliament-177273

Stupp, C. (2017, November 17). Juncker is 'sincerely in favour of social Europe'. EurActiv. Retrieved from https://www.euractiv.com/section/economy-jobs/ interview/juncker-is-sincerely-in-favour-of-socialeurope-mep-rodrigues

ter Haar, B. P., \& Copeland, P. (2010). What are the future prospects for the European social model? An analysis of EU equal opportunities and employment policy. European Law Journal, 16(3), 273-291.

Zeitlin, J., Pochet, P., \& Magnussen, L. (2005). The open method of coordination in action. Brussels: P.I.E.Peter Lang.

\section{About the Author}

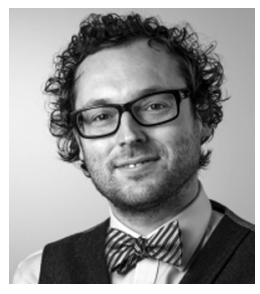

Paul Copeland is Reader of Public Policy at QMUL. His research and teaching focuses on public policy and the political economy of European integration, particularly in the context of the EU's social dimension, and the UK's relationship with the EU. His most recent monograph Governance and the European social Dimension was published in 2020 by Routledge. 